\title{
Agro-ecological variations of sheath rot disease of rice caused by Sarocladium oryzae and DNA fingerprinting of the pathogen's population structure
}

M. Tajul Islam Chowdhury ${ }^{1}$, M. Salim Mian' ${ }^{2}$ M.A. Taher Mia², M.Y. Rafii ${ }^{3}$ and M.A. Latif ${ }^{2,3}$

${ }^{1}$ Life and Earth Science Group, National University, Gazipur, Bangladesh 2Plant Pathology Division, Bangladesh Rice Research Institute, Gazipur, Bangladesh ${ }^{3}$ Department of Crop Science, Faculty of Agriculture, Universiti Putra Malaysia, Serdang, Selangor, Malaysia

Corresponding author: M.A. Latif

E-mail: alatif1965@yahoo.com

Genet. Mol. Res. 14 (4): 18140-18152 (2015)

Received August 29, 2015

Accepted October 6, 2015

Published December 23, 2015

DOI http://dx.doi.org/10.4238/2015.December.23.1

ABSTRACT. To examine the impact of regional and seasonal variations on the incidence and severity of sheath rot, a major seed-borne disease of rice caused by Sarocladium oryzae, data on incidence and severity were collected from 27 selected fields in the Gazipur, Rangpur, Bogra, Chittagong, Comilla, Gopalgonj, Jessore, Manikgonj, and Bhola districts of Bangladesh in rain-fed and irrigated conditions. Cultural variability of 29 pathogen isolates obtained from 8 different locations was studied on potato dextrose agar (PDA) and genetic variability was determined by DNA fingerprinting using variable number tandem repeat-polymerase chain reaction markers. Overall, disease incidence and severity were higher in irrigated rice. Disease incidence and severity were highest in the Bhola district in rain-fed rice and lowest in irrigated rice. Mycelial growth of 29 representative isolates was found to vary on PDA and the isolates were 
divided into 6 groups. The range of the overall size of conidia of the selected isolates was $2.40-7.20 \times 1.20-2.40 \mu \mathrm{m}$. Analysis of the DNA fingerprint types of the 29 isolates of $S$. oryzae, obtained from the amplification reactions, revealed 10 fingerprinting types (FPTs) that were $80 \%$ similar. FPT- 1 was the largest group and included 13 isolates (44.8\%), while FPT-2 was the third largest group and included 3 isolates. Each of FPT-3, 4, 5, and 6 included only 1 isolate. We observed no relationship between cultural and genetic groupings.

Key words: Incidence; Lineage group; Molecular markers; Rice; Sheath rot disease

\section{INTRODUCTION}

Sheath rot is a seed-borne disease caused by Sarocladium oryzae (Sawada) W. Gams \& D. Hawks. The disease is prevalent in all rice-growing countries in Asia and the United States (Ou, 1985), causing significant damage to rice crops. There were no reports regarding the occurrence of sheath rot disease caused by Sarocladium oryzae in Bangladesh until 1973 (Shahjahan et al., 1994). In Bangladesh, sheath rot was initially a minor disease, but is now considered to be a major destructive disease prevalent in rain-fed and irrigated rice ecosystems and affects both local and modern rice varieties; interestingly, the incidence appears to be high in modern cultivars (Miah et al., 1985). Sheath rot disease damages the uppermost flag leaf sheath covering the young panicles (Amin et al., 1974; Shahjahan et al., 1977). Panicle exertion depends on the time of infection and severity of the disease. Under severe conditions, the panicle remains inside the leaf sheath (Estrada et al., 1984; Naeimi et al., 2003). The booting stage of the rice plant is the most vulnerable stage for infection, causing maximum damage (Nasu, 2004). While emerging from the infected sheath, the young panicles are affected, increasing the number of chaffy, discolored, and shriveled grains and reducing the weight and number of healthy grains (Chakravarty and Biswas, 1978; Estrada et al., 1984; Vidhyasekaran et al., 1984). Mia et al. (1986) reported a direct relationship between disease severity and grain discoloration. They also reported that germination of discolored grain was reduced by $76.5 \%$. An inhibitory effect on seed germination by this pathogen has also been reported in other countries (Ekefan et al., 2006). Yield loss incurred by sheath rot infection was found to be as high as 70\% in Thailand (Surin et al., 1977), 9.6-26\% in India (Chakravarty and Biswas, 1978), and $52.8 \%$ yield loss at the International Rice Research Institute in the Philippines (Estrada et al., 1984). Yield loss in Bangladesh because of this disease in different seasons was found to be 18.9-47.4\% (Shahjahan et al., 1994). Thus, sheath rot disease is very destructive to rice crops. The most economically and environmentally friendly approach for disease management is the development and use of resistant varieties. Little information is available regarding disease resistance-related studies of this pathogen. Limited information on the screening of rice varieties or germplasms and the identification of resistant sources is available (Reddy et al., 2000). However, the development of durable, resistant varieties is necessary for understanding the pathogen population, particularly regarding genetic and pathogenic variability. Ayyadurai et al. (2005) reported the genotypic variability of S. oryzae among isolates collected from North East and South India. Differences in the virulence among some isolates of $S$. oryzae were also observed in India (Yadav and Thrimurty, 2006). In Bangladesh, no information is available 
on the incidence of this disease and its relationship with agro-ecological regions, season, and the diversity of this pathogen. Such information is essential for initiating a program for the development and deployment of varieties with resistance and reducing environment pollution. This study was conducted to examine the relationship between regional and seasonal variations and the incidence and severity of sheath rot disease as well to determine the morphological and genetic variability of S. oryzae isolates collected from different agro-ecological zones in Bangladesh.

\section{MATERIAL AND METHODS}

\section{Incidence and severity of sheath rot disease and collection of infected samples}

Nine regions representing different agro-ecological zones (AEZs), including Gazipur (AEZ-28), Rangpur (AEZ-2), Bogra (AEZ-3), Chittagong (AEZ-18), Comilla (AEZ-19), Gopalgonj (AEZ-12), Jessore (AEZ-11), Manikgonj (AEZ-8), and Bhola (AEZ-18), were selected to survey the incidence and severity of sheath rot disease from 2006-2007 in rain-fed field and irrigated fields.

From each of the 9 districts, 3 large fields were selected; from each of the 3 field plots, at least 1 hectare was marked for collection of disease data following a 'W' pattern. Disease incidence (DI) and disease severity (DS) were recorded for a total of 25 hills from each plot. The survey was conducted from booting stage to maturity stage of the rice plants across the 9 districts in Bangladesh.

\section{Pathogen collection, isolation, and purification}

A total of 29 isolates of S. oryzae were collected from 9 districts of Bangladesh (Table 1). From infected flag leaf sheath, the pathogen was isolated using the tissue planting method. The infected portion of the flag leaf sheath along with healthy tissue was cut into small pieces. Infected tissue and seeds were separately surface-sterilized by washing with sterilized water and then immersing in $10 \%$ bleach solution for $2 \mathrm{~min}$. The samples were rinsed twice with sterile water and blotted dry. The blotted dry leaf sheath and seed of each sample were placed on 2-3 layers of moist blotting paper in Petri dishes and incubated at $21^{\circ} \pm 1^{\circ} \mathrm{C}$ under $12-\mathrm{h}$ alternate exposure to near ultraviolet light and darkness for 3-4 days. The fungus developed and sporulated on the infected leaf tissue or seed surface, generally near the empty glum. Using a low-power stereomicroscope, a few conidia were removed with a needle spread onto potato dextrose agar (PDA) medium. The inoculated Petri dishes were then placed in an incubator at $28^{\circ} \mathrm{C}$ for 3 days. The contamination-free cultures were transferred to a new PDA plate and exposed to a 12-h cycle of near ultraviolet light and dark period for conidial production. When a sufficient number of conidia were produced, the pure culture was diluted using the serial dilution plate method. A single colony was then transferred to new PDA plates and allowed to grow, and stock cultures in a test tube were preserved in a refrigerator until further use.

\section{Cultural characteristics of Sarocladium oryzae}

\section{Mycelial growth of the isolates on PDA}

A total of 29 fungal isolates from 9 districts was cultured on PDA media to examine the growth rate. The colony diameter of the isolates grown in 9-cm Petri dishes was measured after 8 
days of incubation at $25^{\circ} \pm 1^{\circ} \mathrm{C}$ under ambient laboratory conditions. To determine the conidial size of different isolates, the length and breadth of 50 conidia from each isolate were measured after preparing a conidial suspension for each isolate grown on PDA for 7 days and incubated at $25^{\circ} \pm$ $1^{\circ} \mathrm{C}$ under a $12-\mathrm{h}$ alternate cycle of near ultraviolet light and darkness. Before the measurement, the oculometer was adjusted with the stage micrometer. The mean data and standard deviation are presented.

\begin{tabular}{|c|c|c|}
\hline Isolate designation \# & Locations of collection & Date of collection \\
\hline 1 & Gazipur & $24 / 7 / 2006$ \\
\hline 2 & Gazipur & $20 / 8 / 2006$ \\
\hline 3 & Gazipur & $20 / 8 / 2006$ \\
\hline 4 & Gazipur & $30 / 7 / 2006$ \\
\hline 5 & Rangpur & $14 / 8 / 2006$ \\
\hline 6 & Rangpur & 20/8/2006 \\
\hline 7 & Rangpur & $20 / 8 / 2006$ \\
\hline 8 & Rangpur & $10 / 9 / 2006$ \\
\hline 9 & Rangpur & 2/9/2006 \\
\hline 10 & Bogra & $5 / 7 / 2006$ \\
\hline 11 & Bogra & $10 / 7 / 2006$ \\
\hline 12 & Bogra & $23 / 7 / 2006$ \\
\hline 13 & Bogra & 21/7/2006 \\
\hline 14 & Bogra & 20/8/2006 \\
\hline 15 & Bogra & $20 / 8 / 2006$ \\
\hline 16 & Comilla & $30 / 7 / 2006$ \\
\hline 17 & Comilla & $4 / 7 / 2007$ \\
\hline 18 & Comilla & $10 / 8 / 2007$ \\
\hline 19 & Comilla & $10 / 8 / 2007$ \\
\hline 20 & Chittagong & $30 / 7 / 2007$ \\
\hline 21 & Chittagong & $4 / 7 / 2007$ \\
\hline 22 & Chittagong & $10 / 8 / 2007$ \\
\hline 23 & Chttagong & $27 / 8 / 2007$ \\
\hline 24 & Gopalgonj & $17 / 7 / 2006$ \\
\hline 25 & Jessore & $26 / 7 / 2007$ \\
\hline 26 & Jessore & $27 / 8 / 2007$ \\
\hline 27 & Jessore & $24 / 8 / 2007$ \\
\hline 28 & Bhola & $10 / 7 / 2007$ \\
\hline 29 & Bhola & 8/7/2007 \\
\hline
\end{tabular}

\section{Molecular characterization of Sarocladium oryzae}

For culture preparation, 29 purified cultures were grown in potato dextrose (PD) medium without agar. A portion of the $30-\mathrm{mL}$ broth was poured into a $125-\mathrm{mL}$ conical flask and sterilized as described above. A 4-mm mycelial block from a 6-day-old culture of S. oryzae grown on PDA was aseptically transferred to PD broth in each flask. A total of 29 isolates were used for this study and each isolate was transferred in 3 flasks and incubated at room temperature for 5 days. The mycelial mat was then collected, squeezed in cheesecloth to remove the liquid, and then blotted with tissue paper. The mycelium was then wrapped in aluminum foil and stored in a freezer at $-20^{\circ} \mathrm{C}$ until further use.

DNA was extracted using the method described by Latif et al. (2008) with some modifications. Frozen mycelium was ground into powder using a mortar and pestle. Approximately $20 \mathrm{mg}$ ground mycelium was placed into 1.5-mL centrifuge tubes and homogenized with $500 \mu \mathrm{L}$ extraction buffer (100 mM ethylenediaminetetraacetic acid, $100 \mathrm{mM}$ Tris- $\mathrm{HCl}, 250 \mathrm{mM} \mathrm{NaCl}$ ), followed by resuspension by vortexing. Next, $50 \mu \mathrm{L} 10 \%$ sodium dodecyl sulfate was added to grounded mycelium 
in the centrifuge tube, mixed thoroughly by inversion, and incubated in a water bath for $30 \mathrm{~min}$ at $65^{\circ} \mathrm{C}$. To each tube, $200 \mu \mathrm{L} 3 \mathrm{M}$ sodium acetate $(\mathrm{pH} 5.2)$ was added, mixed gently, and kept on ice for $15 \mathrm{~min}$ to burst the cells and denature the protein. The mixture was then centrifuged at $12,500 \mathrm{~g}$ for $10 \mathrm{~min}$ in a refrigerated centrifuge (Hawk 15/05) at $4^{\circ} \mathrm{C}$. The supernatant was transferred into a fresh tube and the tube containing mycelia and other impurities was discarded. To the supernatant, $500 \mu \mathrm{L}$ chloroform was added and mixed thoroughly using a vortex mixer. This was then centrifuged at $12,500 \mathrm{rpm}(9800 \mathrm{~g})$ for $15 \mathrm{~min}$ at $4^{\circ} \mathrm{C}$. The upper aqueous layer containing DNA was carefully placed into a fresh micro tube so that the interface layer remained undisturbed. To the DNA solution, 2 volumes pure ethanol was added, the sample was incubated on ice for $10 \mathrm{~min}$ to allow the DNA molecules aggregate, and then spun again for $5 \mathrm{~min}$ as described above. The supernatant was discarded using a wide-bore pipette. DNA pellets at the bottom of the tube were washed with $70 \%$ ethanol, dried in a vacuum for 5-10 min, and re-suspended in 50-100 $\mu \mathrm{L}$ TE buffer depending on the pellet size. Dissolved DNA was stored at $-20^{\circ} \mathrm{C}$.

The purity and concentration of genomic DNA was quantified using a Nanodrop spectrophotometer (Nanodrop Technologies, Wilmington, DE, USA). The quality of genomic DNA isolated by electrophoresis on an $0.8 \%$ agarose gel in $1 \mathrm{X}$ TBE buffer.

To amplify the DNA fragments, variable number tandem repeat-polymerase chain reaction (VNTR-PCR) was used. VNTR-PCR amplifies short tandem-repeated DNA sequences in the fungal genome. This method uses a single primer to amplify a complex of fragments from repeat regions within the fungal genome. The primer RY with the sequence 5'-CAGCAGCAGCAGCAG-3' was used for VNTR analysis. The following master mix for the $20-\mu \mathrm{L}$ reactions was prepared: $1 \mathrm{X}$ PCR Buffer $(2.4 \mu \mathrm{L}), 3 \mathrm{mM} \mathrm{MgCl} 2(0.16 \mu \mathrm{L}), 0.2 \mathrm{mM}$ dNTPs $(1 \mu \mathrm{L}), 1$ pmol primer $(2.0 \mu \mathrm{L}), 0.5$ $\mathrm{U}$ Taq polymerase enzyme $(0.2 \mu \mathrm{L})$, and sterile water $(14.24 \mu \mathrm{L})$. Next, $19 \mu \mathrm{L}$ master mix was aliquoted into $0.5-\mathrm{mL}$ PCR tubes and $1 \mu \mathrm{L}$ genomic DNA ( $5 \mathrm{ng} / \mu \mathrm{L})$ of each isolate was added. One drop of mineral oil was added to each PCR tube to prevent evaporation. An Eppendorf Master cycler personal (Hamburg, Germany) was used for amplification. The PCR lid was set to $103^{\circ} \mathrm{C}$ and the following VNTR-PCR protocol was used: a) $94^{\circ} \mathrm{C}, 2 \mathrm{~min}$ (for initial denaturation of DNA), b) $94^{\circ} \mathrm{C}$ for $20 \mathrm{~s}$ (for denaturation), c) $45^{\circ} \mathrm{C}$ for $30 \mathrm{~s}$ (for annealing), d) $72^{\circ} \mathrm{C}$ for $2.5 \mathrm{~min}$ (for extension); the b-d cycle was repeated 35 times, and e) $72^{\circ} \mathrm{C}$ for $5 \mathrm{~min}$ (for final extension); the reaction was held at $4^{\circ} \mathrm{C}$.

After PCR, $2 \mu \mathrm{L} 6 \mathrm{X}$ loading dye was added to each tube and mixed thoroughly. A $2 \%$ agarose gel with 1X TAE was used to separate molecular weight of DNA with marker, $\lambda$ Hindlll. In each of the other wells, PCR products for each isolate with loading dye was loaded and electrophoresed for $3 \mathrm{~h}$ at $80 \mathrm{~V}$. Gels were visualized under ultraviolet light after staining with ethidium bromide. An imaging system was used to visualize the results.

\section{Data analysis}

Survey data were statistically analyzed to determine the level of significance using the MSTAT package program developed by Russel (1986). Differences between pairs of means were compared using Duncan's multiple range test as stated described by Gomez and Gomez (1984). For molecular data analysis, the presence (1) or absence (0) of bands at different positions on the gel against the molecular weight of the marker ( $\phi$ X174) was noted manually and the binary outputs were analyzed using NTSYS-pc version 2.1. A similarity matrix was calculated for cluster analysis using the SAHN subprogram with the unweighted pair group method with arithmetic mean clustering method as implemented in NTSYS-pc. 


\section{RESULTS}

\section{Survey of sheath rot disease}

In irrigated rice, the severity of sheath rot disease was found to vary significantly with respect to location. Among the 9 locations, DS was the highest in Gopalgonj (58.78\%) and the lowest $(21.59 \%)$ in Bogra. DS in Gopalgonj was statistically similar to that observed in Gazipur (55.7), Jessore (51.5), Chittagong (47.1), and Comilla (43.6). The lowest DS in Bogra was similar to that in Bhola (25.8) and Rangpur (37.5). The DS of sheath rot was moderate in Manikgonj (40.7) (Table 2). Similarly, the highest percent hill infection was observed in Gopalgonj (46.7), and hill infection in Manikgonj, Comilla, and Jessore was statistically similar to that in Goplagonj. The lowest hill infection was found in Bogra (7.8) (Table 2). Tiller infection was also lowest in Bogra (0.81\%), but the highest tiller infection was observed in Manikgonj (4.0\%), which was statistically similar to that in Gopalgonj, Comilla, and Jessore. The minimum incidence in Bogra was similar to those in Bhola, Gazipur, Chittagong, and Rangpur. In rain-fed rice, DS in Gopalgonj and Bhola was similar, but significantly higher (62.3\%) compared to other locations. The lowest DS was found in Comilla $(19.1 \%)$, which was similar to that in Chittagong (33.7\%) and Jessore $(34.5 \%)$. Sheath rot DS at Bogra (42.4\%), Rangpur (41.1\%), and Gazipur (38.1\%) was statistically similar, but significantly higher than that in Comilla and lower than Gopalgonj (Table 2). Percent hill infection in Gopalgonj (48.9\%) was significantly higher compared to other locations. The lowest hill infection was recorded in Comilla (6.7\%) in this season. Hill infection in Bogra, Chittagong, and Rangpur was 9.7, 10.7, and $12.9 \%$, respectively, and these values were statistically similar to that in Comilla. Tiller infection was significantly higher in Gopalgonj (5.82\%). Percent tiller infection in Bogra, Rangpur, Chittagong, and Comilla was similar, but lower than values in other locations. Tiller infection at Bhola, Gazipur, and Jessore was moderate. The overall percentage of occurrence of DS was higher in irrigated rice compared to rain-fed rice, though the difference was not significant (Figure 1).

Table 2. Occurrence of sheath rot disease at different locations in irrigated and rain-fed rice fields from 2006-2007.

\begin{tabular}{|c|c|c|c|c|c|c|c|}
\hline \multirow[t]{2}{*}{ Locations } & \multirow[t]{2}{*}{$A E Z$} & \multicolumn{3}{|c|}{ Irrigated rice, 2006-2007 } & \multicolumn{3}{|c|}{ Rain-fed, 2006} \\
\hline & & $\%$ Disease index & $\%$ Hill infection & $\%$ Tiller infection & $\%$ Disease index & $\%$ Hill infection & $\%$ Tiller infection \\
\hline Bhola & AEZ-18 & 25.8 & 21.0 & 0.88 & $51.8^{\mathrm{ac}}$ & $24.3^{\mathrm{bc}}$ & $2.12^{\mathrm{b}}$ \\
\hline Bogra & AEZ-3 & 21.6 & 7.8 & 0.81 & $42.4^{c}$ & $9.7^{\mathrm{d}}$ & $1.26^{\mathrm{c}}$ \\
\hline Chittagong & AEZ-18 & 47.1 & 15.5 & 1.63 & $33.7^{\mathrm{cd}}$ & $10.7^{d}$ & $1.88^{\circ}$ \\
\hline Comilla & AEZ-19 & 43.6 & 36.4 & 3.00 & $19.1^{\mathrm{d}}$ & $6.7^{\mathrm{d}}$ & $1.95^{\mathrm{c}}$ \\
\hline Gazipur & AEZ-28 & 55.7 & 25.7 & 1.21 & $38.1^{\mathrm{c}}$ & $25.7^{\mathrm{b}}$ & $2.12^{\mathrm{b}}$ \\
\hline Gopalgonj & AEZ-12 & 58.8 & 46.7 & 3.27 & $62.3^{a}$ & $48.9^{a}$ & $5.82^{\mathrm{a}}$ \\
\hline Jessore & AEZ-11 & 51.5 & 31.1 & 2.78 & $34.5^{\mathrm{cd}}$ & $14.2^{\mathrm{b}}$ & $2.42^{\mathrm{bc}}$ \\
\hline Manikgonj & AEZ-8 & 40.7 & 45.7 & 4.00 & $35.0^{\mathrm{cd}}$ & $14.4^{\mathrm{b}}$ & $2.43^{\mathrm{bc}}$ \\
\hline Rangpur & AEZ-2 & 37.5 & 21.3 & 1.80 & $41.1^{\mathrm{c}}$ & $12.9^{\mathrm{cd}}$ & $1.55^{c}$ \\
\hline LSD at $5 \%$ & 17.5 & 20.3 & 1.59 & & 18.4 & 11.7 & 1.97 \\
\hline
\end{tabular}

$\mathrm{AEZ}$ = agro-ecological zone.

\section{Cultural variations among isolates of Sarocladium oryzae}

Mycelial growth of the 29 isolates on the 8th day varied from 17.5-32.5 mm. Based on the growth of the isolates on PDA medium, by 8 days, the isolates were divided into 6 groups. The results are presented in Table 3 and indicate that the growth of 1 isolate from Gazipur was the highest $(32.5 \mathrm{~mm})$, which was distinctly different from other isolates and thus placed in group 
1. Isolates no. 24 and 26 collected from Gopalgonj and Jessore showed similar growth and were placed in group 2. Three isolates, 2 from Bogra (no. 10 and 13) and 1 (no. 27) from Chittagong, were in group 3. Of the 29 isolates tested, 8 isolates showed similar mycelial growth. Among these, isolates no. 2 and 4 were from Gazipur; 11 and 14 from Bogra; 16, 18, 19 from Chittagong; and no. 21 from Comilla (group 4). The largest number of isolates (9) was in group 5, of which isolate no. 3 was from Gazipur, nos. 12, 13, and 15 were from Bogra, no. 17 was from Chittagong, nos. 20 and 22 were from Comilla, and isolate nos. 28 and 29 were from Bhola. Six isolates made up group 6 , of which isolates 5-8 were from Rangpur and no. 25 was from Jessore.

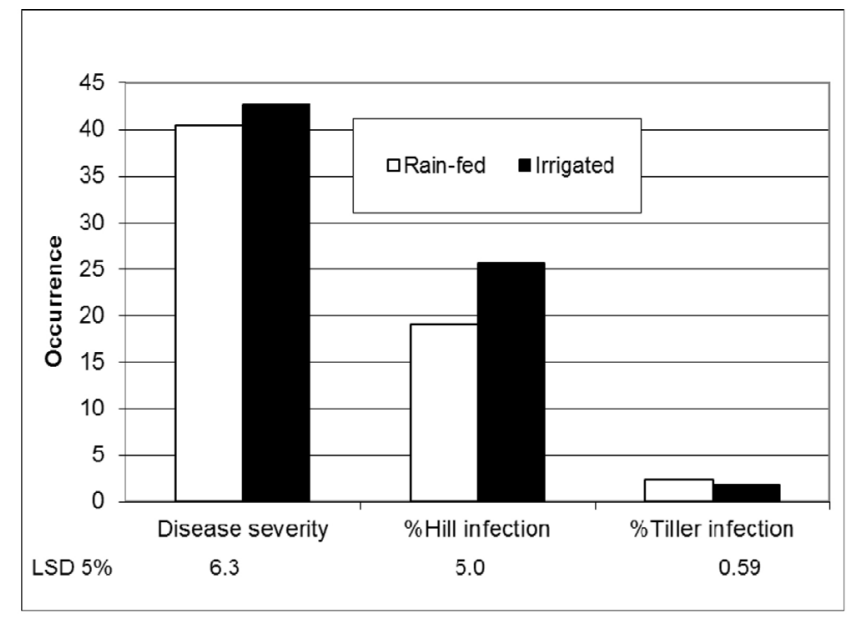

Figure 1. Impacts of seasonal variations on the occurrence of sheath rot disease irrespective of location.

\begin{tabular}{|c|c|c|c|c|}
\hline \multirow[t]{2}{*}{ Group } & \multirow[t]{2}{*}{ Isolate Designation } & \multirow[t]{2}{*}{ Place of collection } & \multicolumn{2}{|c|}{ Mycelial growth by 8 days $(\mathrm{mm})$} \\
\hline & & & Minimum & Maximum \\
\hline 1 & 1 & Gazipur & - & 32.5 \\
\hline 2 & 24,26 & Gopalgonj, Jessore & 29.0 & 29.7 \\
\hline 3 & $10,13,23$ & Bogra, Chittagong & 26.8 & 27.5 \\
\hline 4 & $2,4,11,14,16,18,19,21$ & Gazipur, Bogra, Comilla, Chittagong & 24.0 & 25.0 \\
\hline 5 & $3,12,15,17,20,22,28,29$ & Gazipur, Bogra, Comilla, Chittagong, Bhola & 21.5 & 23.5 \\
\hline 6 & $5,6,7,8,9,25,27$ & Rangpur, Jessore & 17.5 & 19.5 \\
\hline
\end{tabular}

Mycelial growth within a group varied within $2.0 \mathrm{~mm}$.

\section{Conidia size}

The size of the conidia of the 29 isolates of S. oryzae from 9 locations is shown in Table 4. Among the locations, the minimum length of the conidia was 2.40-3.60 $\mu \mathrm{m}$ and the maximum ranged from 4.80-7.20 $\mu \mathrm{m}$. Similarly, the minimum width ranged from 1.20-2.16 $\mu \mathrm{m}$ and the maximum ranged from $2.37-2.40 \mu \mathrm{m}$ for all isolates. The mean length of the conidia varied individually and independently. The highest mean length $(5.37 \mu \mathrm{m})$ of the conidia was observed in an isolate from Bogra, which was followed by another isolate from the same location with a length of $5.33 \mu \mathrm{m}$. The lowest mean length $(3.40 \mu \mathrm{m})$ of the conidia was produced by an isolate from Bhola. In the same location, the mean length of the conidia varied between isolates. The highest variability in length 
was observed in isolate no. 20 from Chittagong, and isolate no.16 from Comilla showed the lowest variability. With respect to width, the lowest variability was observed in isolate no.16 from Comilla, and isolate no. 2 from Gazipur showed the highest variability. The range in overall size of conidia of the selected isolates was 2.40-7.20 x 1.20-2.40 $\mu \mathrm{m}$. The standard deviation varied between 0.47 and $1.02 \mu \mathrm{m}$ for length and between 0.04 and $0.51 \mu \mathrm{m}$ for width.

Table 4. Conidial measurement of the 29 selected isolates of Sarocladium oryzae from 9 locations in Bangladesh.

\begin{tabular}{|c|c|c|c|c|c|}
\hline \multirow[t]{2}{*}{ Isolate \# } & \multirow[t]{2}{*}{ Place of collection } & \multicolumn{2}{|c|}{ Length $(\mu \mathrm{m})$} & \multicolumn{2}{|c|}{ Width $(\mu \mathrm{m})$} \\
\hline & & Range & Means \pm SD & Range & Means \pm SD \\
\hline 1 & Gazipur & $2.40-4.80$ & $4.16 \pm 0.75$ & $2.16-2.40$ & $2.38 \pm 0.06$ \\
\hline 2 & Gazipur & $3.60-7.20$ & $4.92 \pm 0.58$ & $1.20-2.38$ & $1.70 \pm 0.51$ \\
\hline 3 & Gazipur & $2.40-6.00$ & $4.42 \pm 0.81$ & $1.68-2.40$ & $2.10 \pm 0.33$ \\
\hline 4 & Gazipur & $2.45-5.80$ & $4.30 \pm 0.63$ & $1.24-2.39$ & $1.75 \pm 0.50$ \\
\hline 5 & Rangpur & $2.40-6.00$ & $4.32 \pm 0.81$ & $1.68-2.40$ & $2.20 \pm 0.28$ \\
\hline 6 & Rangpur & $3.60-5.98$ & $4.04 \pm 0.67$ & $1.68-2.39$ & $2.22 \pm 0.29$ \\
\hline 7 & Rangpur & $3.59-6.00$ & $4.68 \pm 0.85$ & $1.92-2.40$ & $2.37 \pm 0.10$ \\
\hline 8 & Rangpur & $2.88-4.78$ & $3.93 \pm 0.59$ & $1.91-2.37$ & $2.26 \pm 0.22$ \\
\hline 9 & Rangpur & $2.87-4.73$ & $3.92 \pm 0.58$ & $1.90-2.38$ & $2.25 \pm 0.20$ \\
\hline 10 & Bogra & $3.60-7.20$ & $5.37 \pm 0.80$ & $1.68-2.40$ & $2.28 \pm 0.23$ \\
\hline 11 & Bogra & $3.59-7.19$ & $4.88 \pm 0.93$ & $1.67-2.39$ & $2.28 \pm 0.23$ \\
\hline 12 & Bogra & $3.58-7.18$ & $5.33 \pm 0.86$ & $1.66-2.40$ & $2.38 \pm 0.13$ \\
\hline 13 & Bogra & $3.59-7.17$ & $4.83 \pm 0.91$ & $1.67-2.39$ & $2.29 \pm 0.22$ \\
\hline 14 & Bogra & $2.40-4.80$ & $3.67 \pm 0.53$ & $1.44-2.40$ & $2.07 \pm 0.38$ \\
\hline 15 & Bogra & $2.64-4.78$ & $3.46 \pm 0.59$ & $1.44-2.39$ & $1.76 \pm 0.23$ \\
\hline 16 & Comilla & $2.88-4.80$ & $3.71 \pm 0.47$ & $1.68-2.38$ & $2.10 \pm 0.26$ \\
\hline 17 & Comilla & $2.88-4.80$ & $3.78 \pm 0.48$ & $1.44-2.39$ & $1.95 \pm 0.38$ \\
\hline 18 & Comilla & $2.40-4.81$ & $3.60 \pm 0.71$ & $2.16-2.40$ & $2.39 \pm 0.04$ \\
\hline 19 & Comilla & $3.60-4.80$ & $4.20 \pm 0.61$ & $1.92-2.37$ & $2.30 \pm 0.20$ \\
\hline 20 & Chittagong & $3.58-7.20$ & $5.04 \pm 1.02$ & $1.44-2.40$ & $2.27 \pm 0.22$ \\
\hline 21 & Chittagong & $3.60-6.00$ & $4.68 \pm 0.91$ & $1.68-2.38$ & $2.23 \pm 0.30$ \\
\hline 22 & Chittagong & $3.59-6.00$ & $4.82 \pm 0.72$ & $1.68-2.39$ & $2.22 \pm 0.26$ \\
\hline 23 & Chttagong & $2.40-6.00$ & $3.99 \pm 0.79$ & $1.44-2.40$ & $2.18 \pm 0.30$ \\
\hline 24 & Gopalgonj & $2.88-4.80$ & $4.26 \pm 0.65$ & $1.68-2.38$ & $2.08 \pm 0.28$ \\
\hline 25 & Jessore & $2.40-4.79$ & $3.86 \pm 0.62$ & $1.92-2.40$ & $2.12 \pm 0.25$ \\
\hline 26 & Jessore & $3.60-4.80$ & $4.20 \pm 0.61$ & $1.68-2.37$ & $2.08 \pm 0.34$ \\
\hline 27 & Jessore & $2.40-6.00$ & $4.00 \pm 0.78$ & $1.44-2.39$ & $2.06 \pm 0.40$ \\
\hline 28 & Bhola & $2.40-4.80$ & $3.64 \pm 0.62$ & $1.92-2.40$ & $2.26 \pm 0.22$ \\
\hline 29 & Bhola & $2.40-6.79$ & $3.40 \pm 0.64$ & $1.68-2.39$ & $1.98 \pm 0.22$ \\
\hline
\end{tabular}

\section{Molecular characterization of Sarocladium oryzae}

Amplification of DNA fragments of the 29 isolates of S. oryzae following the VNTR-PCR protocol and through agarose gel showed different banding patterns or fingerprint types (FPTs) of the isolates. Among the 29 isolates, isolate no. 3 produced only a single band. Some bands were common in a number of isolates; however, some isolates had specific bands at particular locations. The band marked in isolate 4 was absent in isolates $5,6,7,8,9$, and 10 , among others. The double band observed in isolate 16 was not common to all isolates (Figure 2).

Analysis of the DNA FTPs of the 29 isolates of $S$. oryzae, obtained by VNTR-PCR using NTSYS software revealed different clusters based on similarity. At the $80 \%$ similarity level, the isolates were grouped into 10 clusters (Figure 3). Ten clusters were represented as 10 FPTs. FPT-1 was the largest group and included 13 isolates (isolate nos. 1, 5, 6, 7, 8, 9, 10, 12, 13, 14, 15, 17, and 18). Group 2 included isolates 23, 27, and 28 and was the third largest group. Groups 3, 4, 5, and 6 were represented by a single isolate, nos. $22,11,20$, and 26 , respectively. Three isolates 
(nos. 2, 3, and 29) showed similarity at the $80 \%$ level and were included in group 7. Groups 8 and 9 were represented by isolate no. 4 and 16, respectively. The second largest group was group 10 , which was represented by 4 isolates (nos. 19, 21, 24, and 25). The results observed in the dendrogram (Figure 3) clearly indicated that genetic variability in S. oryzae exists in Bangladesh.

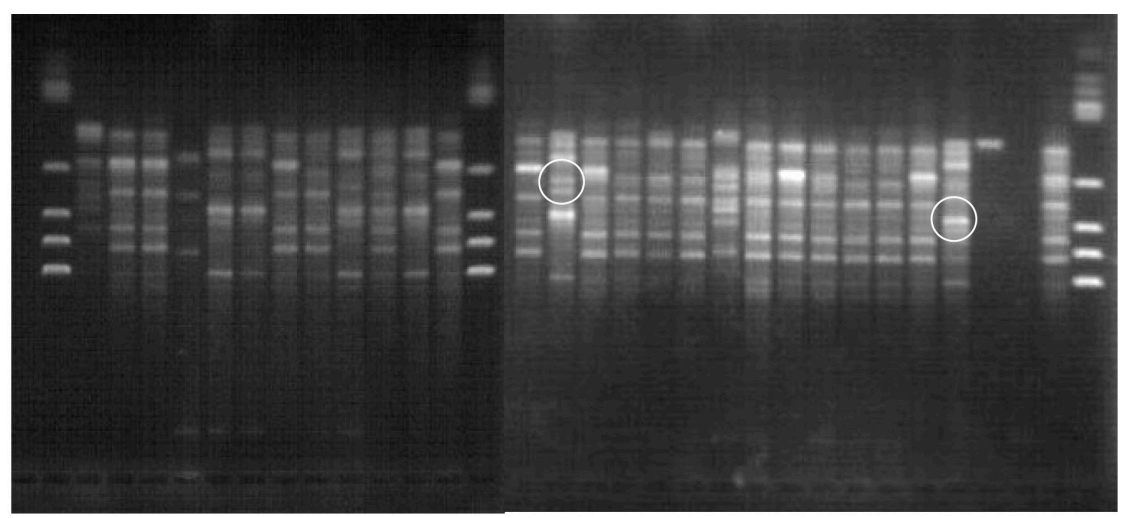

M 292827262524232221201918 M $1716151413 \quad 12 \quad 1110 \quad 9 \quad 8 \quad 7 \quad 6 \quad 5 \quad 4 \quad 3 \quad 2 \quad 1 \quad$ M

Figure 2. DNA fingerprints of different isolates of Sarocladium oryzae using primer RY.

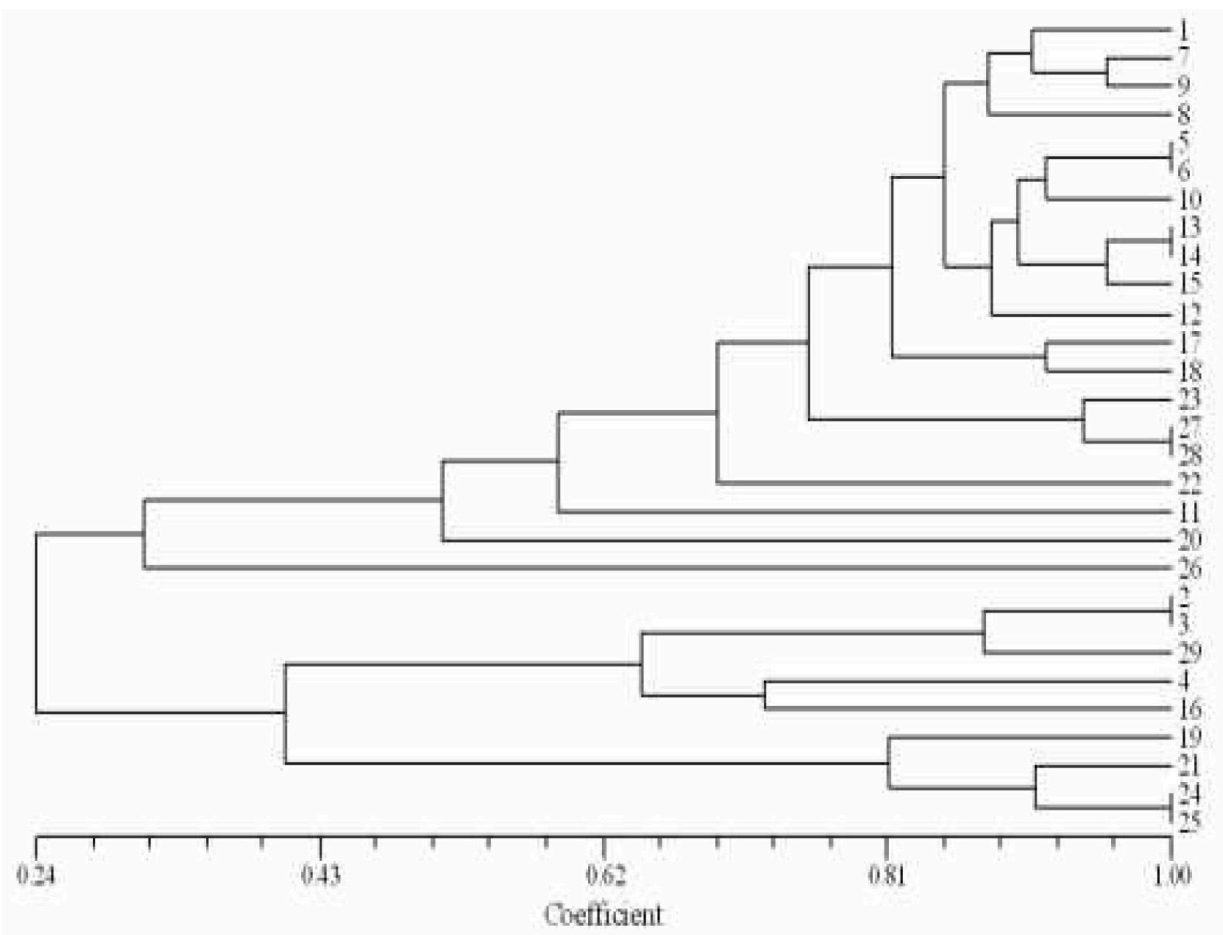

Figure 3. Dendrogram showing clusters of the 29 isolates of Sarocladium oryzae assessed by VNTR analysis with primer RY on an agarose gel. 
Among the 10 FPTs, the most predominant was FPT-1, which included $44.8 \%$ of the total population of 29 isolates (Table 5). This FPT was distributed in 4 districts, including Bogra, Comilla, Gazipur, and Rangpur. With respect to predominance, FPT-1 was highest, followed by FPT-10, which represented $13.6 \%$ of the population and was distributed in Chittagong, Comilla, Gopalgonj, and Jessore. The third highest category was FPT-2, which represented $10.3 \%$ of the population and was distributed in Bhola, Chittagong, and Jessore. The number of populations in group 7 was similar to that in group 2; however, the populations were distributed in 4 locations, including Bhola, Chittagong, Gazipur, and Jessore. Each of the other groups, including groups 3, 4, 5, 6, 8, and 9, was represented by only 1 isolate, found in Chittagong, Bogra, Jessore, Gazipur, and Comilla, respectively. Two isolates from Bhola were represented by groups 2 and 7 . From Bogra, 6 isolates were tested, of which 5 represented group 1 and 1 was in group 4 . Four isolates from Chittagong were distributed in 4 groups, with each group containing only 1 isolate, respectively. Four isolates from Comilla were in groups 1, 9, and 10. Four isolates from Gazipur were in groups 1, 7, and 8. Only one isolate from Gopalgonj was placed in group 10. From Jessore, 3 isolates were in groups 2,6 , and 10, and all 5 isolates from Rangpur showed similar banding patterns and were placed in group 1 (Table 5).

\begin{tabular}{|c|c|c|c|c|c|c|c|c|c|}
\hline \multirow[t]{2}{*}{ Group (FPT) } & \multicolumn{8}{|c|}{ Number of isolates is each group with respect to location } & \multirow[t]{2}{*}{ Total } \\
\hline & Bhola & Bogra & Chittagong & Comilla & Gazipur & Gopalgonj & Jessore & Rangpur & \\
\hline 1 & & 5 & & 2 & 1 & & & 5 & $13(44.8 \%)$ \\
\hline 2 & 1 & & 1 & & & & 1 & & $3(10.3 \%)$ \\
\hline 3 & & & 1 & & & & & & $1(3.4 \%)$ \\
\hline 4 & & 1 & & & & & & & $1(3.4 \%)$ \\
\hline 5 & & & 1 & & & & & & $1(3.4 \%)$ \\
\hline 6 & & & & & & & 1 & & $1(3.4 \%)$ \\
\hline 7 & 1 & & & & 2 & & & & $3(10.3 \%$ \\
\hline 8 & & & & & 1 & & & & $1(3.4 \%)$ \\
\hline 9 & & & & 1 & & & & & $1(3.4 \%)$ \\
\hline 10 & & & 1 & 1 & & 1 & 1 & & $4(13.6 \%)$ \\
\hline Isolate \# & 2 & 6 & 4 & 4 & 4 & 1 & 3 & 5 & 29 \\
\hline Types & 2 & 2 & 3 & 4 & 3 & 1 & 3 & 1 & \\
\hline
\end{tabular}

*Figures in parenthesis are percentages of total population.

The similarity matrix among the 10 different FPTs, as shown in Table 6, indicated that similarity was highest (98.3\%) between FPT-2 and FPT-10. In addition, more than $90 \%$ similarity was observed between FPT-2 and FPT-7 (97.7\%), FPT-7 and FPT-10 (95.2\%), FPT-1 and FPT-2 (93.8\%), FPT-1 and FPT-7 (93.2\%), FPT-2 and FPT-8 (92.0\%), and FPT-7 and FPT-8 (91.4\%). The most distantly related group in the present study was FPT-6 and FPT-9, for which the similarity was only 50\%. A similar relationship was observed between FPT-5 and FPT-6 and FPT-5 and FPT-9. The results indicated that although the 29 isolates of $S$. oryzae were separated into $10 \mathrm{FPTs}$, all FPTs are not equally related with respect to similarity, which ranged from $50.0-98.3 \%$.

\section{DISCUSSION}

Variations in the incidence and severity of sheath rot with respect to seasons and locations were clear based on our results. The overall DS was higher in irrigated rice compared to that in rain- 
Table 6. Inter cluster similarity matrix of 10 fingerprint types of 29 isolates of Sarocladium oryzae (dice similarity coefficient).

\begin{tabular}{|c|c|c|c|c|c|c|c|c|c|c|}
\hline Groups & 1 & 2 & 3 & 4 & 5 & 6 & 7 & 8 & 9 & 10 \\
\hline 1 & 1.000 & & & & & & & & & \\
\hline 2 & 0.938 & 1.000 & & & & & & & & \\
\hline 3 & 0.754 & 0.799 & 1.000 & & & & & & & \\
\hline 4 & 0.78 & 0.825 & 0.641 & 1.000 & & & & & & \\
\hline 5 & 0.732 & 0.777 & 0.593 & 0.619 & 1.000 & & & & & \\
\hline 6 & 0.696 & 0.741 & 0.557 & 0.583 & 0.535 & 1.000 & & & & \\
\hline 7 & 0.932 & 0.977 & 0.793 & 0.819 & 0.771 & 0.736 & 1.000 & & & \\
\hline 8 & 0.875 & 0.92 & 0.736 & 0.762 & 0.714 & 0.678 & 0.914 & 1.000 & & \\
\hline 9 & 0.696 & 0.741 & 0.557 & 0.583 & 0.535 & 0.50 & 0.736 & 0.678 & 1.000 & \\
\hline 10 & 0.913 & 0.983 & 0.774 & 0.80 & 0.752 & 0.716 & 0.952 & 0.895 & 0.716 & 1.000 \\
\hline
\end{tabular}

fed rice, though the difference was not significant. The occurrence of sheath rot disease in rice has been reported in various rice-growing countries, including Bangladesh (Agnihothrudu, 1973; Amin et al., 1974; Shahjahan et al., 1977; Shahjahan et al., 1994). In India, Reddy et al. (2001) reported a higher incidence and severity of sheath rot disease in rain-fed rice than in irrigated rice. However, little information is available regarding seasonal variations and the occurrence of this disease.

Overall, the incidence and severity of sheath rot disease was higher in irrigated rice compared to rain-fed rice, but both rice ecosystems were equally conducive to the development of sheath rot disease. In the present study, higher DS was observed in irrigated rice, which disagrees with the results of a previous report (Reddy et al. 2001). In the same season, environmental factors such as temperature and relative humidity may vary with respect to location, influencing disease development. Therefore, DS is not expected to be high during a particular season throughout the country. Singh and Raju (1981) reported that the level of minimum temperature and relative humidity influenced the development of sheath rot disease. Disease development reached a maximum when the minimum temperature was $17^{\circ}-20^{\circ} \mathrm{C}$ and the minimum relative humidity was $40-50 \%$ during the flowering stage. The maximum temperature, maximum relative humidity, rainfall, and sunlight levels could not be correlated with DS.

Mycelial growth on PDA medium and sporulation in different locations indicated cultural variability among the pathogen isolates. Different workers reported different conidial measurements. According to Ou (1985), conidia size ranged from 4.0-9.0 x 1.0-2.5 $\mu \mathrm{m}$. The size of conidia of $S$. oryzae according to Brady (1980) was 1.8-13 x 1-1.6 $\mu \mathrm{m}$ from culture; in 50 isolates from different countries, including Bangladesh, the length was 3.25-8.0 $\mu \mathrm{m}$ and width was 1.2-2.5 $\mu \mathrm{m}$. The standard deviation was $0.36-1.56 \mu \mathrm{m}$ for length and was $0.17-0.70 \mu \mathrm{m}$ for width. The conidial measurement obtained by Groth (1992) was 3.5-9.0 x 1.0-2.5 $\mu \mathrm{m}$.

VNTR-PCR revealed the wide genetic diversity among the populations of $S$. oryzae in Bangladesh. This is the first report from Bangladesh regarding the population structure of $S$. oryzae. Within the population, variation was observed regarding the predominance of FPTs or groups. The population of Comilla showed the maximum variability and the population of Rangpur was found to be relatively uniform. At all other locations, there were variations among the isolates. However, in Gopalgonj, only 1 isolate was used in the experiments; therefore, no inferences could be made regarding pathogen variability in this location. Among the population, group 1 was the most predominant and widely distributed. Therefore, this group should be examined when first developing varieties resistant to sheath rot disease. Analysis of DNA FPTs clearly indicated genetic variability among the population of $S$. oryzae in Bangladesh. Twenty-nine isolates were grouped 
into 10 FPTs; FPT-1 was predominant, representing $44.8 \%$ of the total population. Isolates from Comilla were found to be more variable, but those from Rangpur were relatively uniform.

Variability among the population of S. oryzae has also been reported in India (Ayyadurai et al., 2005). Genetic variability among isolates collected from North East and South India, studied using VNTR with the GF and MR primers, revealed 2 major clusters. In the present study, isolates from different locations in Bangladesh were grouped into 10 clusters based on VNTR with primer RY. Bridge et al. (1997) also reported that VNTR derived RY primers are suitable for generating genetic fingerprints of some filamentous fungi, including $S$. oryzae. They also found that the MR and GY primers are equally suitable for this purpose. No other studies have examined the genetic fingerprinting of $S$. oryzae; however, variability among the population of this pathogen with respect to toxin production has been reported (Nandakumar et al., 2007). Latif et al. (2011 and 2013) successfully used VNTR with the GF, MR, and RY markers to examine the phylogenetic relationships among resistant and susceptible genotypes of rice blast, tungro, and ufra diseases. Development of durable disease-resistant varieties depends on pathogen variability (Ayyadurai et al., 2005; Miah et al., 2013). By understanding the population structure of S. oryzae, a plant breeder can enhance varietal development. Therefore, our results are important for identifying the FTPs of $S$. oryzae.

\section{ACKNOWLEGMENTS}

The authors sincerely acknowledge the authorities of Bangladesh Rice Research Institute and National University, Gazipur, Bangladesh for financial support.

\section{REFERENCES}

Agnihothrudu V (1973). Acrocylindrium oryzae Sawada-Sheath rot on paddy. Kawaka 1: 69-71.

Amin KS, Sharma BD and Das CR (1974). Occurrence in India of sheath rot of rice caused by Acrocylindrium. Plant Dis. Repotr. 58: 358-360.

Ayyadurai N, Kirubakaran SI, Srisha S and Sakthivel N (2005). Biological and molecular variability of Sarocladium oryzae, the sheath rot pathogen of rice (Oryza sativa L.). Curr. Microbiol. 50: 319-323.

Brady BLK (1980). CMI description of pathogenic fungi and bacteria. Nos 673 and 674, Commonwealth Agricultural Bureaux, Farnham Royal, UK.

Bridge PD, Pearce DA, Rivera A and Rutherford MA (1997). VNTR-derived oligonucleotides as PCR primers for population studies in filamentous fungi. Lett. Appl. Microbiol. 24: 426-430.

Chakravarty DK and Biswas S (1978). Estimation of yield loss in rice affected by sheath rot. Can. Plant Dis. Sur. 62: $226-227$.

Ekefan EJ, Ironenge IB and Vange T (2006). Effect of seed treatment with tolchlofos-methyl on percentage incidence of seed borne fungi and germination of rice (Oryza sativa) in Makurdi, Nigeria. Indian J. Agr. Sci. 76: 450-453.

Estrada BA, Torres CC and Bonman JM (1984). Effect of sheath rot on some yield component. Int. Rice Res. Newslett. 9: 14. Gomez KA and Gomez AA (1984). Statistical procedures for agricultural research. 2nd edn. John Wiley and Sons, New York. Groth D (1992). Sheath rot. In: Webster and Gunnell (1992) ed. Compendium of rice diseases (Webster RK and Gunnell PS, eds.). APS Press, St. Paul, 61.

Latif MA, Soon Guan T, Mohd Yusoh O and Siraj SS (2008). Evidence of sibling species complex in brown planthopper, Nilaparvata lugens complex detected from short and long primer random amplified polymorphic DNA fingerprints. Biochem. Genet. 46: 520-537.

Latif MA, Rafii Yusop M, Motiur Rahman M and Bashar Talukdar M (2011). Microsatellite and minisatellite markers based DNA fingerprinting and genetic diversity of blast and ufra resistant genotypes. C. R. Biol. 334: 282-289.

Latif MA, Rahman MM, Ali ME, Ashkani S, et al. (2013). Inheritance studies of SSR and ISSR molecular markers and phylogenetic relationship of rice genotypes resistant to tungro virus. C. R. Biol. 336: 125-133.

Mia MAT, Sharma NR and Miah SA (1986). Preliminary studies on the impact of sheath rot on rice seeds. Bangladesh J. Plant Pathol. 2: 71-73. 
Miah G, Rafii MY, Ismail MR, Puteh AB, et al. (2013). Blast resistance in rice: a review of conventional breeding to molecular approaches. Mol. Biol. Rep. 40: 2369-2388.

Miah SA, Shahjahan AKM, Hossain MA and Sharma NR (1985). Survey of rice disease in Bangladesh. Trop. Pest Manag. 31: 208-213.

Naeimi S, Okhovvat SM, Hedjaroude GA and Khosravi V (2003). Sheath rot of rice in Iran. Commun. Agric. Appl. Biol. Sci. 68: 681-684.

Nandakumar R, Babu S, Amutha G, Raguchander T, et al. (2007). Variation in toxin production among isolates of Sarocladium oryzae, the rice sheath rot pathogen. Plant Pathol. J. 6: 120-126.

Nasu H (2004). Seed transmission of sheath rot fungus of rice and its infection site. Jpn. J. Phytopathol. 70: 18-21.

Ou SH (1985). Rice disease. Comonwealth Mycological Institute, Kew, England, 380.

Reddy MM, Reddy CS and Reddy AGR (2000). Management of sheath rot of rice through balanced application of nutrients. Indian J. Plant Prot. 28: 43-47.

Reddy MM, Reddy CS and Reddy AGR (2001). Influence of weather parameters and insect pest populations on incidence and development of sheath rot of rice. Indian Phytopathol. 54: 179-184.

Russel DF (1986). MSTAT-C Package Programme. Crop and Soil Science Department, University of Michigan, Ann Arbor, MI.

Shahjahan AKM, Harahap Z and Rush MC (1977). Sheath rot of rice caused by Acrocylindrium oryzae in Lousiana. Plant Dis. Reptr. 63: 220-223.

Shahjahan AKM, Akanda SI, Mondal AH and Nahar NS (1994). Relationship of sheath rot (Sarocladium oryzae) severity to yield loss of rice. Bangladesh J. Bot. 23: 211-215.

Singh RA and Raju CA (1981). Studies on sheath rot of rice. Int. Rice Res. Newsl. 6: 11-12.

Surin A, Arunyanant P and Disthaporn S (1977). Yield loss due to sheath rot of rice. Plant Pathology Division, Annual Report, 1978, Dept. of Agriculture, Thailand, MOAC.

Vidhyasekaran P, Ranganathan K, Raja Manikam B and Radhakrishnan J (1984). Quality of rice grain from sheath rot affected plants. Int. Rice Res. Newslett. 9: 19.

Yadav VK and Thrimurty VS (2006). Status and source of resistance of sheath rot of rice. Ann. Plant Prot. Sci. 14: $424-427$. 